\title{
NURSING CARE IN BLOOD TRANSFUSION: A TOOL FOR PATIENT MONITORING ${ }^{1}$
}

\author{
Daiana de Mattia², Selma Regina de Andrade
}

\footnotetext{
${ }^{1}$ Paper taken from the thesis - Nursing care in hemotherapy: designing tools for quality management, developed in the Programa de Pós-Graduação em Gestão do Cuidado de Enfermagem, Universidade Federal de Santa Catarina (UFSC), in 2014.

${ }^{2}$ M.Sc. in Nursing Care Management. Nurse, UFSC University Hospital. Florianópolis, Santa Catarina, Brazil. E-mail: daimattia@ gmail.com

${ }^{3}$ Ph.D. in Nursing. Professor, Departamento de Enfermagem, Programa de Pós-Graduação em Enfermagem, UFSC. Florianópolis, Santa Catarina, Brazil. E-mail: selma.regina@ufsc.br
}

\begin{abstract}
Qualitative study, developed through discussion groups, with the objective to elaborate, along with nurses, a tool to monitor patients submitted to blood transfusion. Study participants were 11 nursing professionals, being three nursing technicians and eight nurses. Data were analyzed with the content analysis technique, resulting in two categories: Quality of nursing care for patients undergoing blood transfusion and monitoring of patients submitted to blood transfusion. It was identified that professionals are able to understanding the concept of quality and seek to implement actions to achieve a good standard of patient care. In line with the current regulations, the professionals have structured a tool for recording information on blood transfusion, serving as a tool to monitor patients who are receiving this therapy. This research is intended to help identify and intervene early in the onset of transfusion reactions.
\end{abstract}

DESCRIPTORS: Nursing care. Quality management. Blood transfusion.

\section{CUIDADOS DE ENFERMAGEM NA TRANSFUSÃO DE SANGUE: UM INSTRUMENTO PARA MONITORIZAÇÃO DO PACIENTE}

\begin{abstract}
RESUMO: Estudo de abordagem qualitativa, desenvolvido por meio de grupos de discussão, com o objetivo de elaborar, juntamente com profissionais de enfermagem, um instrumento de monitorização do paciente submetido à transfusão sanguínea. Participaram do estudo 11 profissionais de enfermagem, sendo três técnicos e oito enfermeiros. Os dados foram analisados com a técnica de análise de conteúdo, originando duas categorias: Qualidade no cuidado de enfermagem ao paciente submetido à transfusão sanguínea e monitorização do paciente submetido à transfusão de sangue. Identificou-se que os profissionais compreendem o conceito de qualidade e procuram implementar ações para alcançar um padrão ótimo de cuidado ao paciente. Em consonância com a norma vigente, os profissionais estruturaram um instrumento que permitirá o registro das informações sobre a transfusão de sangue, servindo como ferramenta para monitorar o paciente submetido a essa terapêutica. Espera-se contribuir para identificação e intervenção precocemente, no aparecimento de reações transfusionais. DESCRITORES: Cuidados de enfermagem. Gestão da qualidade. Transfusão de sangue.
\end{abstract}

\section{CUIDADOS DE ENFERMERÍA EN TRANSFUSIÓN DE SANGRE: UNA HERRAMIENTA PARA EL MONITOREO DEL PACIENTE}

RESUMEN: Estudio cualitativo, desarrollado a través de grupos de discusión, con objeto de elaborar, junto con las enfermeras, un instrumento de monitoreo de pacientes sometidos a la transfusión de sangre. Los participantes del estudio fueron 11 enfermeras, tres técnicos de enfermería y ocho enfermeras. Los datos fueron analizados con la técnica de análisis de contenido, lo que resultó en dos categorías: Calidad de la atención de enfermería para los pacientes sometidos a la transfusión de sangre y el monitoreo del paciente sometido a una transfusión de sangre. Se identificó que los profesionales entienden el concepto de calidad y tratan de poner en práctica acciones para lograr un buen nivel de atención al paciente. De acuerdo con la normativa vigente, los profesionales han estructurado un instrumento para registrar la información sobre las transfusiones de sangre, que sirve como una herramienta para monitorear el paciente sometido a esta terapia. Se espera ayudar a identificar e intervenir temprano en la aparición de reacciones transfusionales.

DESCRIPTORES: Atención de enfermería. Gestión de la calidad. Transfusión sanguínea. 


\section{INTRODUCTION}

Blood has always been present in the history of humanity, in the belief that it sustained and could save lives. Nevertheless, centuries of studies were needed to discover its true importance and therapeutic role. ${ }^{1}$

In the Brazilian hemotherapy system, the confirmed first transmission of the Acquired Immunodeficiency Virus (AIDS) in 1988 stands out as the starting point to reorganize the National and State Blood Policies. ${ }^{2}$

Today, hemotherapy in the country is regulated by a standard ${ }^{3}$ and decree ${ }^{4}$ on hemotherapy procedures and best practices in the blood cycle, ranging from the donor capitation process to the blood transfusion of blood, its components and blood derivatives originating from human blood..$^{3-4}$

Blood transfusion institutions are responsible for maintaining registers related to the transfusion in patient's records, such as date, start and end date of the blood transfusion, vital signs at the beginning and end, origin and identification of the blood component bags, identification of responsible professionals and records of transfusion reactions. ${ }^{4}$ In addition, the vital signs (temperature, breathing frequency, blood pressure and pulse) of patients submitted to the procedure need to registered immediately after the beginning and after the end; monitoring during the first ten minutes of the transfusion by a qualified health professional; and patient monitoring throughout the transfusion. ${ }^{3}$ These actions permit not only the early detection of any adverse reactions, but also their reporting.

The blood transfusion should be appropriate to the patient's health needs, delivered in time and correctly administered. Even when delivered in accordance with the recommended standards, correctly indicated and administered, the blood transfusion involves a health risk. This risk refers to the transfusion reactions during or after the blood transfusion, besides the fact of being related to it. ${ }^{5}$ The complications include those that are due to bacterial contamination, acute hemolytic reactions caused by incompatibility of the $\mathrm{ABO}$ system, anaphylactic reactions, fluid overload, among others. These complications may be non-immune, and may be associated with human error; or immune, linked to the organic response mechanisms to the blood transfusion. ${ }^{6}$

To avoid the possible damage caused by blood transfusion, the nursing records are funda- mental elements of patient care. Based on these records, multidisciplinary communication can be established, permitting the continuity of care. They are also relevant to qualify the reporting of transfusion reactions by providing information on the patient in the pre, trans and post-transfusion period. $^{7}$

A direct mutual relation exists between transfusion safety and quality management, as health service quality means offering less risk to the patient, based on the orchestration and search to maximize the care and benefit. ${ }^{8}$ Therefore, the establishment of planning and a risk management policy, such as consolidated protocols in the organization for example, contribute to the safety and benefit the stakeholders: patients, collaborators and the institutions. ${ }^{9}$

In the health context, in which the consumer is the patient, a quality management system is intended to improve the efficacy of the services provided, in line with the patient's requisites and satisfaction. In that sense, it is highlighted that the professionals who work at these services should be trained and alert in order to prevent, identify, approach and treat possible transfusion reactions. ${ }^{10}$ At these services, the nursing team is highlighted, considering that its activities can significantly minimize the risks for the patient and avoid damage, managing the transfusion process efficiently. ${ }^{11}$

Although nursing plays a fundamental role in hemotherapy, nursing research on this theme is still limited. In a bibliographic study about scientific nursing production in Hemotherapy, Hematology and Bone Marrow Transplantation between 2000 and 2004, 88 publications were found, of which 73 came from congress proceedings. The studies mainly came from the Southeast, with a predominance of the quantitative-qualitative approach and limited nursing production. This can be justified by the fact that this is a recent nursing specialty in Brazil that is still being consolidated. ${ }^{12}$

The search for texts in the Virtual Health Library, using the key words "nursing" and "hemotherapy", covering the period between 2005 and 2013, also revealed few publications. The findings were related to the nurses' activities in blood donor screening ${ }^{13}$ and risk management, ${ }^{14}$ being responsible for reporting transfusion reactions. Only two studies were found that were specifically related to blood transfusion. One discussed the assessment of nursing records in hemotherapy ${ }^{15}$ and the other the assessment of nursing professionals' knowledge on hemotherapy and transfusion safety. ${ }^{11}$ This reality 
demonstrates that further research is needed in hemotherapy nursing.

At the University Hospital (UH) where the study was undertaken, professionals from the sector called Transfusion Agency take part in the transfusion process. This agency is responsible for selecting and installing the blood components. The responsibility for monitoring the transfusion and the patient is shared with the nursing team, which assists the patient at inpatient and outpatient services. To put these actions in practice, the need was identified for a standardized blood transfusion registration tool that provides the patient data throughout the transfusion process. At the UH, however, no specific tool is available yet for this purpose in the patient history.

In view of the above, the objective in this study was to elaborate, together with nursing professionals, a tool for monitoring the patient submitted to blood transfusion.

\section{METHOD}

This qualitative study was developed based on discussion groups and was intended to collect data in order to analyze the context the interviewees are part of, as well as their world view. The group's opinion is not the sum of all individual opinions, but the collective construction of ideas. ${ }^{16}$

The study population involved 11 nursing professionals, including three technicians and eight nurses. The inclusion criteria were: nursing team professionals working at the services, chosen intentionally, due to the care particularities they present; who agreed to participate voluntarily by signing the Free and Informed Consent Form.

The data were collected in three discussion groups that took approximately two hours. One of the researchers conducted the groups through guiding questions. The guiding question for the first group was: how do you observe the quality in nursing care for patients submitted to blood transfusion? In the second group: what should be the structure of a tool to monitor blood transfusion patients? The third group: does the constructed tool permit monitoring patients submitted to blood transfusion?

The data were collected in October and November 2013, with the authorization of the Ethics Committee for Research Involving Human Beings (protocol 388.010/2013). In the development of the research, respected the Resolution 466/12, ap- proved by Conselho Nacional de Saúde. The research participants were identified using the letter " $\mathrm{P}$ ", followed by a sequence number, to guarantee the subjects' anonymity.

The voices in the discussion groups were digitally recorded with the participants' authorization and then transcribed. The data analysis was based on content analysis, in three phases: pre-analysis, analytic description and interpretation of the reference framework. ${ }^{17}$ In the pre-analysis, the material transcribed with the participants' statements was transcribed. In the analytic description, this material was analyzed in depth, looking for central themes the participants had transmitted, revealing the following categories: Quality in nursing care for patients submitted to blood transfusion and Monitoring of patients submitted to blood transfusion. In the interpretation phase of the reference framework, these categories were analyzed based on the theoretical framework of quality management. ${ }^{18}$ Based on the discussions, the tool to monitor patients submitted to blood transfusion was structured, which was validated in group.

\section{RESULTS AND DISCUSSION}

Quality in nursing care for patients submitted to blood transfusion

Over time, the health institutions have adopted quality management using efficient management models, which optimize the resources applied, contributing to better productivity and satisfaction for users and health care professionals. ${ }^{19}$

In the discussion groups, the participants manifested some concepts of health quality management.

Doing well what one does, with scientific knowledge and with the smallest possible error margin, fulfilling the requisites needed to be as good as possible (P3).

Satisfying the patient, aiming for safe, respectful, efficient and competent care (P2).

The care quality concept Pan American Health Organiztion ${ }^{20}$ proposes corresponds to the degree of satisfaction of the service users, guaranteeing that they receive effective and safe care, with a level of professional excellence, in view of existing social and cultural values.

Thus, it was observed that the participants have background knowledge on the theme, as their perceptions are in accordance with the concept of health care quality. 
The concepts refer to the pillars of quality in health, ${ }^{18}$ as follows: efficiency, corresponding to the ability to obtain the best result at the lowest cost: efficacy, the ability of medical science to offer improvements in individuals' health and wellbeing; effectiveness, with a relation between the actual benefit the health system or care offers and the potential result of an ideal system; optimization, corresponds to the maximization of the benefit in relation to the economic cost of its resources; acceptability, which is the adaptation of medical and health care to the expectations, desires and values of the patients and their families; legitimacy, refers to the possibility to satisfactorily adapt a service to the community or to society as a whole; equity, corresponds to the appropriate and fair distribution of the services and benefits to all members of the community, population or society. ${ }^{18}$

As a part of the health system, nursing understands that an excellent patient care level can only be achieved if quality is sought in care. ${ }^{21}$ Concerning the quality in hemotherapy nursing care, some aspects are essential for safety and quality in blood transfusion. Among these, the participants highlighted specific nursing care in their statements, which should be provided to patients submitted to blood transfusion.

Checking the patient's vital signs, knowing that he may experience a transfusion reaction, what to do in case of a reaction. I take care, check the vital signs, if they are stable. Every 30 minutes, I end up checking the vital signs. He may present a transfusion reaction as early as in the first 10 minutes (P3).

Nursing needs to know the care that guides the blood transfusion and the possible complications this treatment may cause for the patient.

Quite some time ago we had an employee who was returning from her holidays and, on that day, they did 54 transfusions, including cry, platelets. She was a very experienced professionals, very careful, but she exchanged the blood bag. The patient started with a burning feeling in the arm, chest pain and, as soon as she noticed, she called the staff and they were able to revert the condition. Exchanging a blood bag is lethal (P1).

What I notice is that the reactions happen later. The care we didn't take before and we do now is to send the patient away only half an hour after the transfusion (P4).

The professional should know the main indications of blood transfusion, verify important data to prevent errors, advise relatives and patients about the transfusion, attend to transfusion reactions and register the entire process. These professionals' activities tend to guarantee transfusion safety and if the transfusion process is managed efficiently. Nevertheless, professionals with limited knowledge on this specialty and without sufficient skills can cause important damage. ${ }^{10-11}$

Transfusion reactions are problems that can happen during or after the blood transfusion. The signs and symptoms are perceived at the beginning or within 24 hours after the end of the transfusion. ${ }^{6}$ They require immediate action from these professionals, with decision making and priority setting, in order to minimize the damage and discomfort the reaction causes. ${ }^{22}$

For the early detection of these reactions, during the transfusion period, the patient should be observed, during the first ten minutes of the transfusion, by a professional trained for this end, who stays at his/her side to observe possible reactions. ${ }^{3}$ In case of one or more signs and symptoms of a transfusion reaction, the nursing team should be at least capable of taking the measures needed for each of the reaction types. ${ }^{22}$

Transfusion safety and quality management are directly related with the professionals' engagement in this process, taking into account their qualification and knowledge in the area. Tools to help and provide appropriate support on how to proceed in care for blood transfusion patients are fundamental. ${ }^{7-11}$

\section{Monitoring of patients submitted to blood transfusion}

Registering information related to the blood transfusion is extremely important, as it serves to verify whether the transfusion took place in accordance with the standards in force.

Monitoring the entire transfusion process is intended to detect complaints, signs and symptoms that can reveal transfusion reactions. Registering and monitoring the adverse events associated with the transfusion contribute to guarantee the safety and quality control of hemotherapy services. ${ }^{6}$

For the nursing team, this registry provides legal support concerning the quality of patient care. Therefore, the more and the better the nursing team registers its actions, the more it is valuing its work, besides favoring patient safety. ${ }^{15}$

In the course of the discussion groups, based on the participants' statements, a tool was structured to monitor patients submitted to blood transfusion. 
Using guiding questions, topics were listed that should be present in the tool, as well as the content each topic should present, as described in Table 1. It should be clarified that the topics on the transfusion routines were discussed in accordance with the 2011 standard, in force when the discussion groups were held, and which was not changed in the legislation currently in force. ${ }^{3-4}$

Table 1 - Topics and contents of monitoring tool for patients submitted to blood transfusion. Florianópolis-SC, 2014

\begin{tabular}{|l|l|}
\hline \multicolumn{1}{|c|}{ Topics } & \multicolumn{1}{c|}{ Content } \\
\hline Patient identification & $\begin{array}{l}\text { Patient name, mother's name, age, birth date, diagnosis, file number, room/bed, inpa- } \\
\text { tient service, blood type, transfusion data: previous transfusion, transfusion reaction, } \\
\text { need for preparation for the transfusion, result of irregular antibody test, identifica- } \\
\text { tion of irregular antibodies, erytrocytary phenotyping when performed, compatibil- } \\
\text { ity test, result of laboratory tests. }\end{array}$ \\
\hline Pre-transfusion & $\begin{array}{l}\text { Number of blood component bag, type of blood component, verification of double } \\
\text { checking, vital signs, start date and time of transfusion, access route (peripheral, cen- } \\
\text { tral, port cath), access site, orientation to patient or responsible caregiver about proce- } \\
\text { dure and space for observations. }\end{array}$ \\
\hline Transfusion & Vital signs \\
\hline Post-transfusion & Vital signs, end time of transfusion, removal of access, space for observations. \\
\hline Complementary observations & $\begin{array}{l}\text { Observations related to quantity of blood components, transfusion reactions: orienta- } \\
\text { tions, transfusion recommendations. }\end{array}$ \\
\hline
\end{tabular}

The participants considered the content of the patient identification topic as necessary, including specific data (patient name, mother's name, age, birth date, diagnosis, file number, room/bed, inpatient service and blood type) and the transfusion data, such as: previous transfusion, previous reaction; need to prepare for the transfusion, test result of irregular antibodies, identification of irregular antibodies, eritrocytary phenotyping when performed, compatibility test, laboratory test result.

The patient identification is part of safe care. This initiative establishes actions for the patients' safety in health services. Thus, all patients need to be identified in a unique manner, using at least two distinct markers. ${ }^{8}$ The reporting system of transfusion reactions in the United Kingdom identified that approximately $66.7 \%$ of the transfusion reactions reported in that country are associated with errors in the receivers' identification. ${ }^{23}$ This fact evidences the importance of considering this information in the tool.

Knowledge on the patient's transfusion history in the tool is useful, as patients with a history of transfusion reactions, antigens and eritrocitários antibodies may be at an increased risk of a transfusion reaction. ${ }^{6}$ In these cases, professionals assisting patients submitted to blood transfusion should be alert to any report and signal the patient may present during or after the blood transfusion. In addition, in a study developed in 2012, it is appointed that the professionals from an adult intensive care service found it important to have available information on the blood type in the patient history. ${ }^{7}$

Concerning the pre-transfusion data, the need was addressed to include, besides the vital signs (blood pressure, cardiac frequency, respiratory frequency and temperature), start date and time of the transfusion, access route (peripheral, central, port cath), access site, device used (single, shared), orientation to patient or responsible caregiver about the procedure and space for observations.

The data the participants listed are included in the legislation, which recommends the verification and registration of the patient's vital signs at least before the start and at the end of the transfusion. ${ }^{3}$ This action is fundamental to direct the care during the transfusion process, besides helping in case of a transfusion reaction, either to establish the diagnosis or care for the patient. ${ }^{14}$

Concerning the access route used for the transfusion, it should be compatible for this end, as an inappropriate access causes delay in the transfusion and even the discarding of the blood component if the infusion period exceeds four hours. The high pressure of the flow through the small-lumen catheter can cause the hemolysis of the erythrocytes. ${ }^{24}$

Registering the access site and the device use is essential as, when a pre-existing venous access is chosen, it is important to assess signs of infiltration, inflammation, infection, interaction with parenteral solutions, duration of medication therapy, compat- 
ibility for infusion of blood component. No drug can be infused together with the blood component bag, nor infused in parallel. Five percent glucose solutions can cause hemolysis of the blood cells, while ringer lactate solutions can cause clots due to the presence of calcium. ${ }^{6}$

Including the start date and time of the transfusion is fundamental as the infusion time of each blood component cannot exceed four hours. Thus, writing down the start time of the transfusion provides information to control how long the bag remains at room temperature. ${ }^{14}$ In the same topic, another suggestion made was to include specific space to register the bag number and type of the blood component. Each stage of the hemotherapy process should be registered. The bag number is essential, as it permits tracking the blood component that was transfused. Tracking any blood component is a possibility established by law, as it should permit the investigation of adverse events that may occur during or after the transfusion. ${ }^{3}$

Double checking, when the technician from the transfusion agency and the nursing technician check that the correct blood component is given to the correct patient, was another content the participants suggested. This verification procedure of the data by two technicians, one at a time and at distinct moments, comparing the data, tends to minimize error risks, enhancing the transfusion safety. ${ }^{6}$

Advising the patients or their responsible caregivers about the transfusion is also part of the transfusion safety recommendations and is the role of the entire nursing team, so as to appoint the benefits and possible reactions the transfusion can cause. A study shows that, in the orientation to patients submitted to blood transfusion, the nursing team emphasizes the aspects regarding the benefits of the transfusion, providing little clarification on its risks. That is a problem, as the patient or responsible caregiver's cooperation, informing on any abnormality suggesting a reaction, leads to the early detection of a transfusion, contributing to minimize any damage. ${ }^{11}$

In the topic related to the transfusion period, the participants listed information on the vital signs as necessary. These data permit monitoring the patient throughout the transfusion and identifying possible transfusion reactions early, as this treatment is not free from causing health damage. ${ }^{11}$

The causes of these reactions may be linked with the immunological and non-immunological response. Therefore, the nursing team needs to know about this possible problem and to identify the signs and symptoms early, as this can determine the type of transfusion reaction and decision making for the therapeutic conduct..$^{22}$ The transfusion reactions that happen during and until 24 hours after the blood transfusion still represent almost all reported transfusion reactions. ${ }^{25}$ That demonstrates the need to monitor the patient throughout the transfusion period.

As regards the topic associated with the posttransfusion period, the participants appointed the importance of maintaining records on the vital signs, the end time of the transfusion, space for observations to describe possible adverse reactions and conducts. These data are important, as they permit observing whether the transfusion was concluded within the legally established deadline (maximum of four hours) and the identification of a possible transfusion reaction.

The administration time of the blood component is fundamental as, if it is exceeded, the blood component loses its properties due to the exposure to uncontrolled temperature. ${ }^{26}$ That can also increase the risk of bacterial growth. ${ }^{6}$

In the additional observations, the participants suggested some informative topics useful for their daily practice, such as the blood components the institution uses, the standardized abbreviation of each blood component and the infusion time of each. In addition, an observation was included that no medication should be administered concomitantly with the blood component and a flow chart was constructed in case of suspected transfusion reactions.

A version of the tool for nursing care to monitor blood transfusion patients, resulting from this study, is under evaluation at the component sector of the place of study with a view to future implementation.

\section{FINAL CONSIDERATIONS}

Nursing care to monitor patients submitted to blood transfusion requires a registration tool to guarantee the quality of this procedure. This monitoring tool was constructed in discussion groups based on the experience of professionals who understand the concept of quality and work to implement actions to achieve an excellent patient care standard.

In line with established standards, the professionals structure the tool in view of the particularities of their place of work, listing fundamental data that contributed to quality care. Thus, in a broad sense, the data in the tool can cover all specificities of inpatient and outpatient services at the institution. 
The researchers hope that, based on the tool, all information on the blood transfusion can be registered, ranging from blood component data to the patient's clinical parameters. Its main contribution is the early identification and intervention in situations of transfusion reactions, minimizing the damage and discomfort for the patient. In addition, the importance of nurses' activities and the incipient nature of nursing studies on quality management in transfusion practices in Brazil and internationally are underlined.

The scarce literature and the small number of professionals who participated in the discussion groups were limiting factors, but they did not make it impossible to produce a tool to monitor blood transfusion patients, the focus of this research. This tool will contribute to the safety of transfusions, the quality of hemotherapy services and emphasizes the need for the professionals to effectively participate in the transfusion process. At the same time, the importance of developing this kind of studies is highlighted to produce evidence on the safety of transfusions.

\section{REFERENCES}

1. Fundação Pró-Sangue Hemocentro de São Paulo [internet]. São Paulo. [cited 2013 Jun 29]. Available from: www.prosangue.sp.gov.br/artigos/estudantes.

2. Pereima RSMR, Arruda MW, Reibnitz, KS, Gelbcke FL. Projeto Escola do Centro de Hematologia e Hemoterapia de Santa Catarina: uma estratégia de política pública. Texto Contexto Enferm. 2007; 16(3):546-52.

3. Brasil. Portaria $\mathrm{n}^{\circ} 2.712$, de 12 de novembro de 2013. Redefine o regulamento técnico de procedimentos hemoterápicos. (DF): Diário Oficial da República Federativa do Brasil, 12 de novembro de 2013.

4. Brasil. Resolução Diretora Colegiada: $\operatorname{RDC} n^{\circ} 34$, de 11 de junho de 2014. Dispõe sobre as Boas Práticas no Ciclo do Sangue Brasília (DF): Diário Oficial da República Federativa do Brasil, 11 de junho de 2014.

5. Organização Mundial da Saúde(OMS). Departamento de Tecnologias de Saúde Essenciais. Segurança de transfusões de sangue: processo de transfusão médica e segurança de pacientes. Genebra $(\mathrm{CH})$ : OMS; 2012.

6. Ministério da Saúde (BR), Agência Nacional de Vigilância Sanitária, Hemovigilância: Manual técnico de hemovigilância: investigação das reações transfusionais imediatas e tardias não infecciosas. Brasília (DF): MS; 2007.

7. Souza GF. Instrumento de boas práticas de enfermagem em hemoterapia na unidade de terapia intensiva: uma construção coletiva [dissertação] Florianópolis (SC):
Universidade Federal de Santa Catarina, Programa de Pós-Graduação em Enfermagem; 2012.

8. Ministério da Saúde (BR). Agência Nacional de vigilância sanitária. Programa Nacional de Segurança do Paciente. Anexo 2: Protocolo de Identificação do Paciente. Brasília (DF): MS; 2013.

9. Sociedade Beneficente Israelita Brasileira Albert Einstein (SBIBAE). Qualidade e segurança do paciente. São Paulo (SP): SBIBAE; 2014.

10. Mattia D. Assistência de enfermagem em hemoterapia: construção de instrumentos para a gestão da qualidade [dissertação]. Florianópolis (SC): Universidade Federal de Santa Catarina, Programa de Pós-Graduação em Gestão do Cuidado em Enfermagem; 2014.

11. Ferreira O, Martinez EZ, Mota CA, Silva, AM. Avaliação do conhecimento sobre hemoterapia e segurança transfusional de profissionais de enfermagem. Rev Bras Hematol Hemoter. 2007; 29 (2):160-7.

12. Araújo KM, Brandão MAG, Leta, J. Um perfil da produção científica de enfermagem em hematologia, hemoterapia e transplante de medula óssea. Acta Paul Enferm. 2007; 20(1):82-6.

13. Schõninger N, Duro CLM. Atuação do enfermeiro em serviço de hemoterapia. Cienc Cuid Saúde. 2010; 9(2):317-24.

14. Dias MAM. O enfermeiro na hemovigilância: sua formação e competências [dissertação]. Rio de Janeiro (RJ): Universidade Federal do Rio de Janeiro, Programa de Pós-Graduação e Pesquisa da Escola de Enfermagem Anna Nery; 2009.

15. Santos SP, Tanaka LH, Gusmão A, Abreu RGS, Carneiro IA, Carmagnani MIS. Avaliação dos registros de enfermagem em hemoterapia de um hospital geral. Av Enfermería. 2013; 31(1):103-12.

16. Weller W, Pfaff N. Metodologias da pesquisa qualitativa em educação: teoria e pratica. São Paulo (SP): Vozes; 2010.

17. Bardin L. Análise de conteúdo. Lisboa (PT) Edições 70; 2011.

18. Donabedian A. A gestão da qualidade total na perspectiva dos serviços de saúde. Rio de Janeiro (RJ): Qualitymark; 1994.

19. Burmester H, Pereira JC, Scarpi, MJ. Modelo de gestão para organizações de Saúde. Rev Adm Saúde. 2007; 9(37):125-32.

20. Organização Pan-Americana de Saúde (OPAS). A gestão da qualidade. In: Organização Pan-Americana de Saúde. A transformação da gestão de hospitais na América Latina e Caribe. Brasília (DF): OPAS; 2004.

21. Rocha ESB, Trevizan MA. Quality management at a hospital's nursing service. Rev Latino-am Enfermagem. 2009; 1(2):240-5.

22. Costa JE, Torres CA, Gubert FA, Pinheiro PNC, Vieira NFC. O enfermeiro e o contexto em reações transfusionais. Rev Pesq Cuidado Fund [internet]. 
2011 [cited 2014 Ago 25]; (Supl):. Available from: http:/ / www.seer.unirio.br/index.php/ cuidadofundamental/article/view/2018/pdf_562

23. Smeltzer S, Bare B. Tratado de enfermagem médicocirúrgica. $10^{\mathrm{a}}$ ed. Rio de Janeiro (RJ): Guanabara Koogan; 2005.

24. Achkar R, Arap SS, Arrais C, Biagini S, Callas SH, Cardoso LF, et al. Guia de condutas hemoterápicas. $2^{\text {a }}$ ed. Sociedade Beneficente de Senhoras Hospital Sírio
Libanês; 2010 [cited 2014 Ago 10]. Available from: http:/ / www.hospitalsiriolibanes.org.br/hospital/ Documents/guia-conduta.pdf

25. Ministério da Saúde(BR). Agência Nacional de vigilância sanitária. Boletim de Hemovigilância no 5 . Brasília (DF): MS; 2012.

26. Fidlarczyk D, Ferreira SS. Enfermagem em hemoterapia. Rio de Janeiro (RJ): MedBook Editora Científica Ltda; 2008. 